\title{
Osteoprotective effect of hormone therapy on bone microarchitecture before impaired bone mineral density in ovariectomized rats
}

\author{
Ooferektomili ratlarda kemik mineral dansitesi etkilenmeden önce, hormon \\ tedavisinin kemik mikromimari üzerine koruyucu etkisi
}

\author{
Hasan Terzi', Teksin Çırpan², Rabia Terzi ${ }^{3}$, Ahmet Özgür Yeniel², Hüseyin Aktuğ4, Onur Bilgin² \\ 'Department of Gynecology and Obstetrics, Derince Training and Research Hospital, Kocaeli, Turkey \\ ${ }^{2}$ Department of Gynecology and Obstetrics, Faculty of Medicine, Ege University, Izmir, Turkey \\ ${ }^{3}$ Department of Physical Medicine and Rehabilitation, Derince Training and Research Hospital, Kocaeli, Turkey \\ ${ }^{4}$ Department of Histology, Faculty of Medicine, Ege University, Izmir, Turkey
}

\section{Abstract}

Objective: We aimed to determine the effect of hormone replacement therapy on bone microarchitecture in ovariectomized rats.

Material and Methods: In the Animal Ethics Committee approvedstudy, the effect of treatment with $17 \beta$-estradiol $50 \mu \mathrm{g} / \mathrm{kg}$ and medroxyprogesterone $2.5 \mathrm{mg} / \mathrm{kg}$ on bone architecture and bone mineral density in rats versus ovariectomized control rats over the course of 20 days were evaluated. Femoral and lumbar bone mineral density levels and morphometric measurements were performed.

Results: There were no significant differences in the femoral and lumbar bone mineral density levels between the groups. In the intact control group, the trabecular structures were significantly superior to those in the other groups. Additionally, the osteoblast count was significantly higher while the osteoclast count was significantly lower than in all other groups. Two parameters reflecting trabecular bone microarchitecture, which include the trabecular count and the trabecular area, demonstrated significant improvement in the hormone replacement group when compared to the ovariectomized control group. In the hormone replacement groups, the osteoblast count was significantly higher while the osteoclast count was significantly lower than in the ovariectomized control group.

Conclusion: We suggest that offering estrogen alone or in combination with progestogen can be a beneficial approach in preventing early postmenopausal bone loss regardless of bone mineral density. (J Turkish-German Gynecol Assoc 2012; 13: 261-6)

Key words: Hormone replacement therapy, bone density, ovariectomy, menopause, bone microarchitecture

Received: 24 June, 2012

Accepted: 27 October, 2012

\section{Özet}

Amaç: Çalışmamızda ooferektomili sıçanlarda hormon replasman tedavisinin kemik mikromimari üzerine etkisini değerlendirmeyi amaçladık.

Gereç ve Yöntemler: Çalışmanın hayvan etik komite onayı alındı. $17 \beta$-östradiol $50 \mu \mathrm{g} / \mathrm{kg}$ ve medroksiprogesteron $2.5 \mathrm{mg} / \mathrm{kg}$ tedavisi ile; ooferektomili ve ooferektomi uygulanmayan sıçanlarda 20 günlük tedaviyi takiben kemik mikromimarisi ve kemik mineral yoğunluğa etkileri araştırıldı. Femoral ve lumbal kemik mineral yoğunluk ölçümleri yapıldı.

Bulgular: Gruplar arasında kemik mineral yoğunluk ölçümleri değerlendirildiğinde anlamlı fark bulunmadı. Ooferektomi uygulanmayan kontrol grubunda trabeküler yapılar diğer guplara göre anlamlı yüksek bulundu. Ayrica ooferektomi uygulanmayan kontrol grubunda, diğer gruplara göre; osteoblast sayısı anlamlı yüksek ve osteoklast sayısı anlamlı düşük bulundu.

Sonuç: Tek başına östrojen yada progesteron ile kombine hormon tedavisinin; erken postmenapozal dönemde kemik mineral dansitesine yansımayan kemik kayıplarının önlenmesinde etkili olduğunu düşünmekteyiz. (J Turkish-German Gynecol Assoc 2012; 13: 261-6)

Anahtar kelimeler: Hormon replasman tedavisi, kemik yoğunluğu, ooferektomi, menopoz, kemik mikromimari

Geliş Tarihi: 24 Haziran 2012

Kabul Tarihi: 27 Ekim 2012

\section{Introduction}

Osteoporosis is defined as a reduction in bone mass associated with impaired bone microarchitecture (1). Postmenopausal osteoporosis is the most common type of osteoporosis and causes an imbalance between osteoclastic activity and osteoblastic function; therefore, trabecular continuity and connectivity of the trabecular bone structure are decreased resulting in increased bone fragility and increased fracture risk (2). Impaired bone microarchitecture occurs with the conversion of normal plate-like trabeculae into thinner rodlike structures (3). 
Bone mineral density (BMD) measurement is commonly used in practice for the diagnosis and management of postmenopausal osteoporosis (4). However, it has limitations, such as not allowing for the assessment of microarchitecture, bone geometry, mineralization and intracortical porosity (5). Whether increases in BMD contribute to bone fragility, fracture risk, and the therapeutic efficacy of osteoporosis agents is controversial $(6,7)$. Thus, factors other than BMD, such as bone microarchitecture, should be evaluated for management of postmenopausal osteoporosis and assessment of effects of therapuetic agents. Although new techniques have been developed for more comprehensive evaluation of bone turnover and quality, such as imaging techniques with high-resolution peripheral computerized tomography (CT); whether these novel techniques will be useful in daily practice remains to be seen (8). Clinical trials evaluating the changes of bone microarchitecture during postmenopausal osteoporosis and the effects of therapuetic agents on these changes are needed.

The hormone replacement therapy (HRT) is known to prevent accelerated bone loss $(9,10)$ and improve bone mass in postmenopausal osteoporosis (11). In addition to improvement in $\mathrm{BMD}$, fractures were decreased with hormone therapy (12). In the conjugated ethinyl estradiol (CEE) medroxyprogesterone (MPA) arm of the Women's Health Initiative (WHI) study, active therapy significantly reduced fractures; however, the WHI study population consisted of women who were older than 70 years of age and who had undergone menopause more than 20 years previously (13). On the other hand, patients in the early stages of postmenopause with no complications are usually asymptomatic, leading to underdiagnosing and undertreatment of potential osteoporosis, and patient noncompliance to treatment. Tiihonen et al. (14) reported that women using HRT need more information about the advantages and risks of HRT to increase compliance with the treatment. This information is especially important for women who are hesitant to use HRT.

Therefore it is necessary to determine the effect of widely used HRT on markers other than and with respect to BMD such as bone microarchitecture in early postmenopausal osteoporosis. We hypothesized that bone microarchitecture is impaired before impairment of BMD in postmenopausal osteoporosis and HRT has favorable effect on bone microarchitecture before its well-known effect on BMD. Demonstration of the positive effect of HRT on bone microarchitecture in animal models would provide a basis and preliminary data for further clinical studies to implement the use of HRT starting with the early stages of postmenopausal period. Therefore, in this study, we aimed to investigate the effect of HRT on bone microarchitecture with respect to its effect on BMD in a rat model with $t$ surgically induced early menopause.

\section{Material and Methods}

In the present study, 20 adult female Sprague-Dawley rats weighing between 190 and 250 grams were used. Approval was obtained from the Animal Ethics Committee. Fifteen rats underwent bilateral dorsal ovariectomy (OVX) under combined intramuscular $10 \mathrm{mg} / \mathrm{kg}$ xylazine (Bayer Health Care, Monheim, Germany) and $60 \mathrm{mg} / \mathrm{kg}$ ketamine hydrochloride (Parke Davis, Istanbul, Turkey) anesthesia. Five rats did not undergo oopho- rectomy. Rats were kept at the postmenopausal period for three weeks and were divided into four groups:

Group 1, control group with no OVX and no hormone therapy $(\mathrm{n}=5)$

Group 2, control group with OVX and no hormone therapy (nut oil as placebo $)(n=5)$

Group 3, with OVX and receiving $17 \beta$ estradiol $(n=5)$

Group 4, with OVX and receiving $17 \beta$ estradiol and continuous MPA $(n=5)$

The following medications were administered intra-peritoneally for twenty days: nut oil $1 \mathrm{~mL} / \mathrm{kg}, 17 \beta$ estradiol 50 micrograms/ $\mathrm{kg}$ (Sigma, Germany), MPA $2.5 \mathrm{mg} / \mathrm{kg}$ (Sigma, Germany). The intra-peritoneal route provided optimization and certainty of the hormone therapy dose. Twenty days later, BMD of experimental animals under general anesthesia were measured by Hologic QDR-4500A and a "small animal" program. Measurements were taken with high resolution in two different regions: the left extremity distal femoral diaphysis and the lumbar vertebrae. Intracardiac perfusion was applied to the rats under general anesthesia. Following a thoracic incision, a 20G catheter was inserted into the left ventricle, and a $10 \%$ formaldehyde fixative was given at a rate of $1 \mathrm{cc} / \mathrm{sec} / \mathrm{g}$ into the systemic circulation. Following the perfusion procedure, the left femurs of the animals were dissected and kept at room temperature in a $10 \%$ formaldehyde fixative for 24 hours for histomorphometric analysis. Following fixation, specimens were placed in $10 \%$ formic acid. After decalcification was completed within 7 days, they were taken into routine light microscope follow-up. From the prepared paraffin blocks, transverse sections were obtained in 3-micron thicknesses with a Leica MR 2145 microtome. For morphometric analysis, hematoxylenen-eosin dyed preparations were used (15). Finally, one drop of entellan was added to preparations dried at room temperature and kept at $37^{\circ} \mathrm{C}$ for at least ten days to dry.

\section{Morphometric analyses}

For morphometric analyses, five sections were serially obtained from the left hind extremity distal femoral metaphysis in the paraffin blocks of all animals included in the study. Sections were dyed with hematoxylene-eosin, and digital pictures were taken by 10x objective zoom using an Olympus microscope. The semi-automatic digital system UTHSCSA Image Tool for Windows Version 1.28 was used to measure cortex thickness, trabecular count, trabecular thickness and trabecular area. Osteoblast and osteoclast counts were obtained with 40x magnification $0.5 \mathrm{~mm}$ from the epiphysis plaque (16). Trabecular measurements were obtained from the distal $0.46 \mathrm{~mm}$ of the epiphysis plaque and equal distances from both sides of the cortex in femur preparations (17). The lengths were calculated as pixels with the aid of a program ( 1 pixel=128x10-8 mm). All measurements were taken in accordance with the article by Parfit et al. (17)

\section{Morphometric measurements}

For trabecular thickness $(\mu \mathrm{m})$, measurements were taken at a minimum of fifty different points for every trabecula, and measurements continued to be taken until the mean values became constant $(17,18)$. The trabecular count was obtained by counting all trabeculae and each trabecula parallel to each 
other at $0.46 \mathrm{~mm}$ distal to the epiphysis plaque at equal distances from both sides of the cortex $(16,17)$. The trabecular area $\left(\mathrm{mm}^{2}\right)$ was calculated by determining the borders of the trabeculae in the region where the trabecular count was determined (17-19). Cortical thickness $(\mu \mathrm{m})$ was calculated by mean values of fifty measurements from 3-micron sections in digital pictures of each preparation (17-19). Osteoblast and osteoclast counts were calculated in hematoxylene-eosin dyed preparations with 40x objective zoomed digital pictures using an image analysis program and counting cells around trabeculae $0.5 \mathrm{~mm}$ under the epiphysis plaque (17-19).

\section{Statistical analyses}

All statistical analyses were performed using the Microsoft SPSS 11.0 Windows program. Data were expressed as mean \pm standard deviation and were analyzed by the Chisquare test, the Bonferroni test and the Duncan test. A p-value of $<0.05$ was considered significant

\section{Results}

There was no significant difference among the groups according to lumbar and femoral BMD values $(p>0.05)$. The mean BMD values are shown in Table 1.

When the trabecular count was compared between the control groups (group 1, which is the group with no OVX and no hormone therapy and group 2, which is the group with OVX and no hormone therapy), it was found to have decreased significantly in the OVX control group without hormone therapy (group 2) $(\mathrm{p}=0.008)$. When the trabecular count was compared among the hormone replacement groups (group 3, which is the group with OVX and receiving $17 \beta$ estradiol and group 4 , which is the group with OVX and receiving $17 \beta$ estradiol and continuous MPA) and in the OVX control group without hormone therapy (group 2), the trabecular count was significantly higher in hormone treatment groups $(\mathrm{p}<0.001, \mathrm{p}=0.008$ for groups 3 and 4; respectively). When the trabecular area was compared between the control groups, it was significantly higher in the control group with no OVX (group 1) than the control group with OVX (group 2) $(\mathrm{p}<0.001)$. Additionally, the trabecular area was significantly lower in the control group with OVX (group 2) when compared to the hormone treatment groups $(\mathrm{p}<0.001$, $\mathrm{p}<0.001$ for groups 3 and 4 ; respectively). The distribution of the trabecular structures among the groups is demonstrated in Figure 1.

The trabecular thickness was significantly higher in the control group with no OVX (Group 1) when compared to all other groups $(p<0.001)$. With regard to trabecular thickness, there was no significant difference among the OVX groups. The cortical thickness was significantly higher in the control group with no OVX (Group 1) than in all other groups $(p<0.001)$, whereas there was no significant difference with respect to cortical thickness among the OVX groups ( $p>0.05)$. The results of the morphometric analyses are shown in Table 2 and Figure 2. According to the morphometric measurements, the osteoblast count was significantly higher in the control group with no OVX (Group 1) than in all of the OVX groups $(\mathrm{p}<0.05)$. When the osteoblast count was compared among the OVX groups, it was found to be significantly higher in groups 3 and 4 (hormone treatment groups) than in group 2 (control group with OVX) $(p<0.01)$. The osteoclast count was also significantly higher in the control group with no OVX (Group 1) than in the OVX HRT groups, whereas there was no significant difference with respect to the osteoclast count between the control groups with or without OVX ( $\mathrm{p}>0.05)$. However, when the osteoblast count was evaluated, the osteoclast count ratio was found to be significantly lower in the OVX control groups than in all other groups. In addition, there was no significant difference with respect to this ratio between the intact control group and the OVX HRT groups. The morphometric measurements are provided in Figure 3.

\section{Discussion}

In the present animal experiment, we found that in ovariectomized rats, bone microarchitecture, which was assessed with

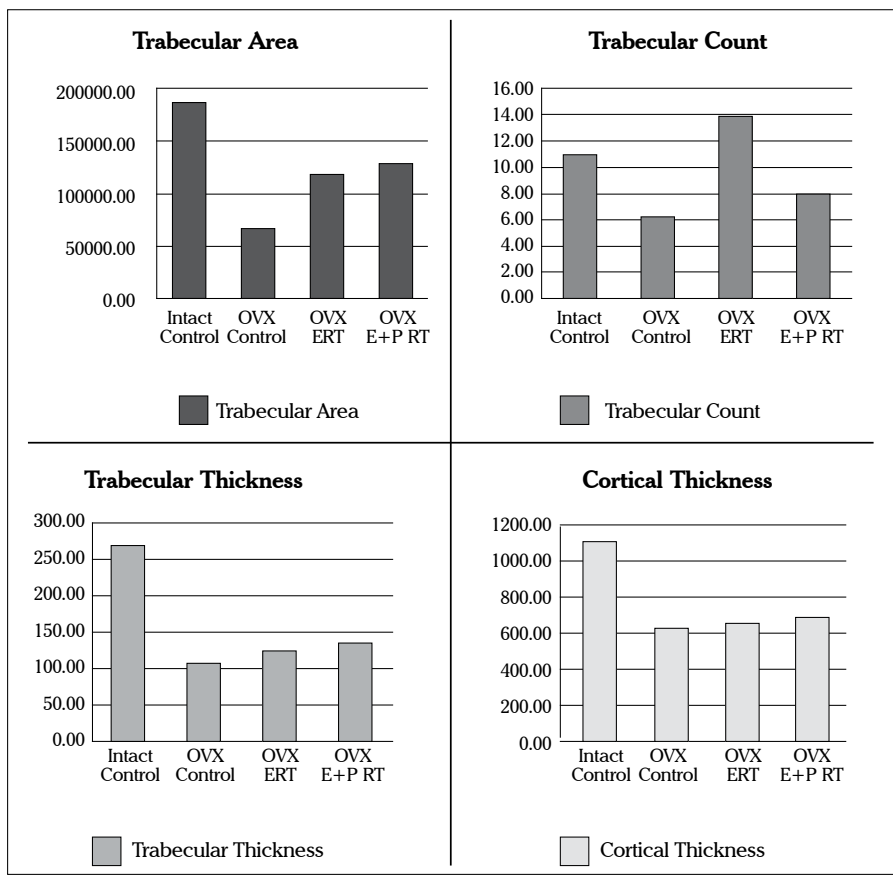

Figure 1. Histological appearance of trabecular structures under Olympus microscope (hematoxylene-eosin, x10). Intact control: control group with no OVX and no hormone therapy, OVX control: control group with OVX and no hormone therapy (nut oil as placebo), OVX ERT: with OVX and receiving $17 \beta$ estradiol, OVX E+PRT: with OVX and receiving $17 \beta$ estradiol and continuous MPA

Table 1. Lumbar and femoral BMD values of study groups (mean \pm SD)

\begin{tabular}{|l|c|c|c|c|}
\hline & Intact control & OVX control & OVX ERT & OVX E+P RT \\
\hline Lumbar BMD & $0.15 \pm 0.03$ & $0.12 \pm 0.03$ & $0.15 \pm 0.02$ & $0.14 \pm 0.01$ \\
\hline Femoral BMD & $0.21 \pm 0.06$ & $0.19 \pm 0.04$ & $0.22 \pm 0.02$ & $0.24 \pm 0.08$ \\
\hline
\end{tabular}


Table 2. Results of morphometric analyses of study groups (mean $\pm \mathrm{SD}$ )

\begin{tabular}{|l|c|c|c|c|}
\hline & Intact control & OVX control & OVX ERT & OVX E+P RT \\
\hline Trabecular count & $11.13 \pm 1.4$ & $6.28 \pm 1.34$ & $14.0 \pm 2.3$ & $8.04 \pm 1.26$ \\
\hline Trabecular thickness & $272.66 \pm 29.65$ & $110.64 \pm 18.79$ & $127.10 \pm 5.41$ & $135.58 \pm 3.15$ \\
\hline Trabecular area & $186731.2 \pm 5026.1$ & $67367.8 \pm 2106.3$ & $121156.8 \pm 5627.8$ & $129912.8 \pm 6062.9$ \\
\hline Cortex thickness & $1104.9 \pm 202.7$ & $622.6 \pm 85.44$ & $667.2 \pm 69.87$ & $693.5 \pm 51.39$ \\
\hline
\end{tabular}

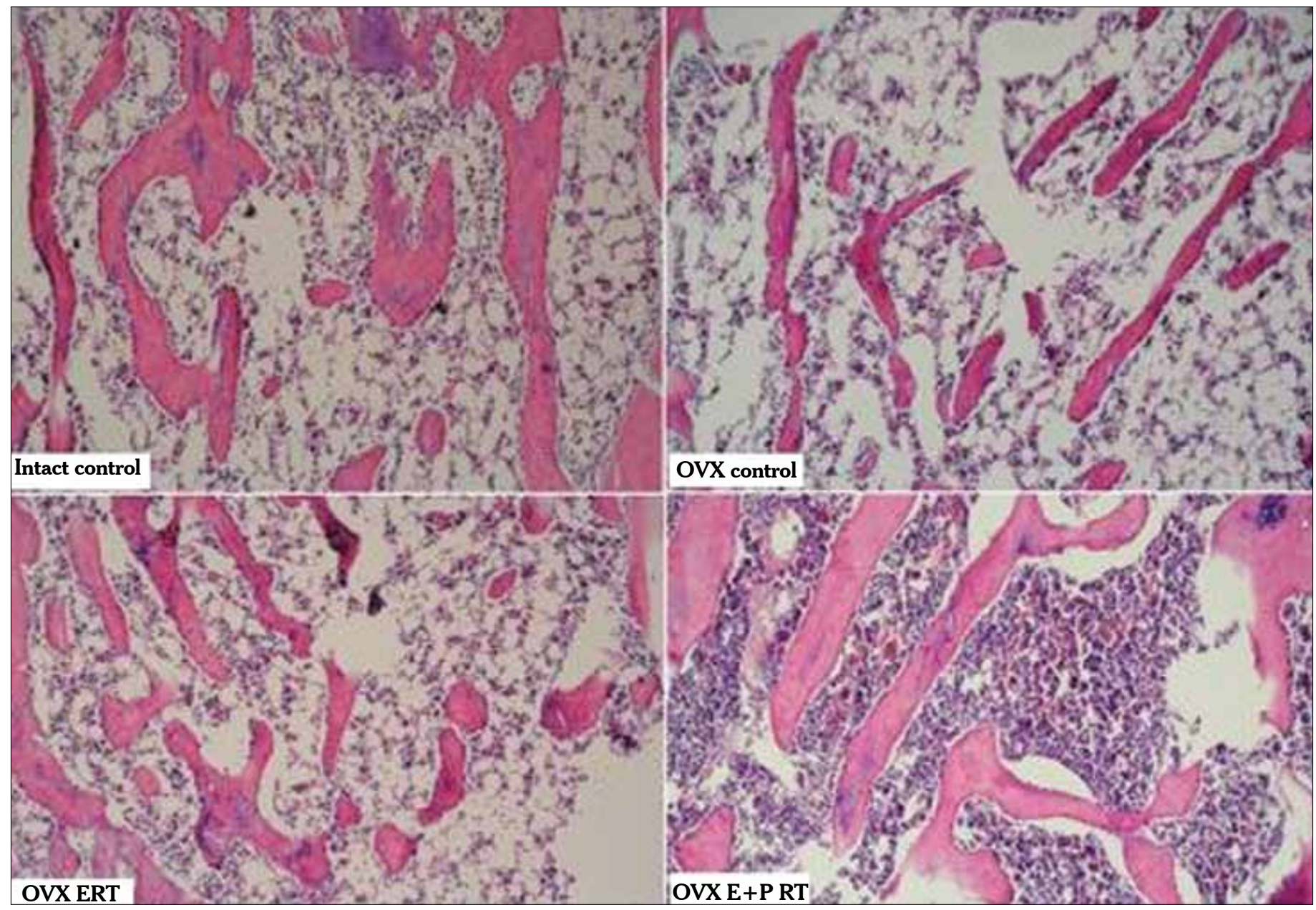

Figure 2. Results of morphometric analyses as mean values. Intact control: control group with no OVX and no hormone therapy, OVX control: control group with OVX and no hormone therapy (nut oil as placebo), OVX ERT: with OVX and receiving 17 $\beta$ estradiol, OVX E+PRT: with OVX and receiving $17 \beta$ estradiol and continuous MPA

morphometric studies, deteriorates before impairment of BMD and this deterioration of bone microarchitecture was corrected with hormone therapy (17 $\beta$ estradiol with or without MPA).

Osteoporosis is a disease with significant medical and socioeconomic costs. It is characterized by an increase in the tendency for fragility fractures and an enhanced risk of other complications, such as pneumonia or thromboembolic disease due to prolonged hospitalization. Prolongation of life has made osteoporosis an important health problem $(2,20)$. Macroscopically, there are two types of bones in the human body skeleton: cortical bone, which constitutes $80 \%$, and trabecular bone (cancellous). The cancellous to cortical bone ratio is approximately 50:50 in the femoral head (21). When bone loss starts due to menopause, aging, etc., cancellous bone is affected earlier than cortical bone. Osteoporosis is described as a reduction in bone mass associated with impaired bone architecture, disruption of trabecular continuity by trabecular perforation, increased bone fragility, increased fracture risk, and thinning and increased porosity of the cortices with the conversion of normal plate-like trabeculae into thinner rod-like structures (3). These changes are the result of the combination of increased osteoclastic activity and reduced osteoblast function that characterizes postmenopausal osteoporosis. The view of affected trabecular bone can be described as stair steps that have decreased in size or been lost (1).

In the present study, the intact control group's mean femoral histomorphometric parameters, such as trabecular count, tra- 


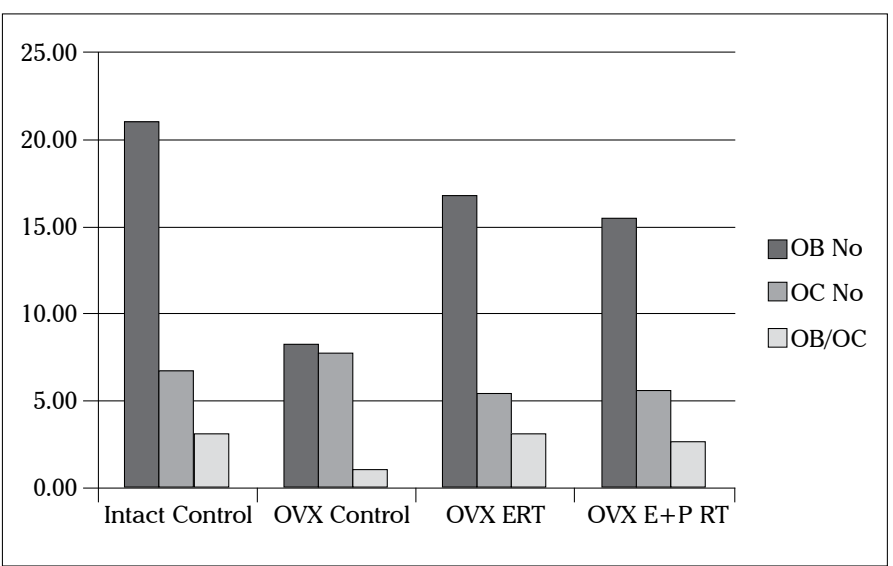

Figure 3. Results of morphometric measurements as mean values. Osteoblast and osteoclast counts were calculated using an image analysis program. Intact control: control group with no OVX and no hormone therapy, OVX control: control group with OVX and no hormone therapy (nut oil as placebo), OVX ERT: with OVX and receiving $17 \beta$ estradiol, OVX E+PRT: with OVX and receiving $17 \beta$ estradiol and continuous MPA. OB no: osteoblast count, $O C$ no: osteoclast count, $\mathrm{OB} / \mathrm{OC}$ :osteoblast:osteoclast count ratio

becular thickness, trabecular area, and cortex thickness, were found to be significantly superior to the OVX control group. In addition, morphometric measurements, such as the osteoblast and osteoclast count, in groups 1 and 2 support an impaired microarchitecture in the OVX rat models. In their study, Bagi et al. (22) investigated the effect of oophorectomy on bone mass and endurance. The bone masses of the femoral neck of rats were evaluated by Dual Energy X-Ray Absorptiometry (DEXA) and histomorphometric parameters using various dynamic and static methods. They determined that the muscular and capsular structures of pelvic articular cartilages in rats resembled those of humans. While endocortical and cancellous bone restructuring following oophorectomy was particularly affected, the ovariectomized group was observed to have a significant decrease in trabecular count, cortical thickness and bone endurance compared with the control group. We found no correlation between impaired bone microarchitecture and femoral BMD. Similarly, in recent years, bone microarchitecture has been increasingly used to determine bone loss or fracture risk when compared to BMD. Ladinsky et al. (23) reported that structural measures obtained at the distal radius in vivo by magnetic resonance imaging (MRI) explained a significant portion of the variation in the total spinal deformity burden in postmenopausal women independent of area BMD. The National Osteoporosis Risk Assessment (NORA) study found that more than one half of women who sustained osteoporotic fractures had BMD T-scores $\geq-2.0$, and a significant portion had BMD levels in a range considered to be normal (24). New specialized techniques have been developed, such as highresolution CT (hrCT), micro CT, high-resolution MR (hrMR) and microMR, that are able to provide structural information about local and systemic skeletal health, the propensity to fracture and the pathophysiology of bone fragility. While quantitative assessment of bone macrostructure can be obtained by DEXA and CT, assessment of trabecular bone microstructure may be obtained by hrCT, microCT, hrMR, and microMR (1). The rela- tionship between osteoporosis and postmenopausal hormone replacement therapy has been widely studied. Several studies from the 1970s reported that treatment with estrogen alone or estrogen plus progestogen at the time of menopause prevented accelerated bone loss $(9,10)$. According to a meta-analysis published in 2002, preparations of estrogen with or without progestogen were significantly more effective than placebo in preserving and increasing BMD (11). Several follow-up studies demonstrated that discontinuation of estrogen therapy caused bone loss similar to that seen in early menopause (24). Early menopause and ovariectomy before age 45 are associated with a lower BMD and a higher osteoporotic fracture rate (25).

Data on the effect of estrogen on bone are inconsistent and range from preserving the existing bone structure $(26,27)$ to having a strong anabolic effect $(19,28)$. Lindsay et al. (29) reported that the effect of progesterone on bone is unclear. In the present study, two parameters reflecting trabecular bone microarchitecture, which include the trabecular count and trabecular area, demonstrated significant improvement in the hormone replacement group when compared to the ovariectomized control group. There was no significant difference between the two groups with respect to other parameters including trabecular and cortical thickness. In addition, there was no significant difference between treatment with estrogen with or without progesterone. Although the action of osteoprotective estrogen remains unclear, it has been suggested that, during estrogen deficiency, bone remodeling is impaired because of an increase in some cytokines, such as TNF-a, IL-1, IL-6, and IL-8. This indirect effect leads to bone resorption through stimulation of osteoclastogenesis (30). In the present study, we found that impaired bone microarchitecture and an imbalance between osteoblasts and osteoclasts in the OVX rats were improved by HRT independent of BMD. This finding suggests that the effect of estrogen deficiency on bone starts in the early period of menopause and that HRT reverts these changes. In a novel study, Komm et al. (31) examined the effect of daily treatment with bazedoxifene, conjugated estrogens, or both treatments combined on bone mass, bone architecture, bone strength, and the biochemical markers of bone turnover in ovariectomized rats over the course of 12 months. The investigators reported that treatment with conjugated estrogens alone or in combination with bazedoxifene completely prevented the ovariectomized-induced loss of BMD at the lumbar spine and proximal femur (31). Batukan et al. (32) found that estrogen in combination with simvastatin increased the BMD of proximal femur and lumbal vertebra effectively in rats. In addition, the WHI studies have demonstrated that estrogen with or without progestogen can prevent hip and vertebral fractures in an unselected population of women (level of evidence: A) (25).

Taking into account the duration of treatment in the present study, the main finding of this study is that the bone microarchitecture was improved in the HRT group without loss of BMD.

This study had some limitations. First, the number of rats in each study group was considerably small. We kept the total number of rats low for ethical reasons. Second, biochemical markers of bone metabolism could not be measured due to technical inadequacy in our hospital. In spite of these limitations, this animal study showed that hormone therapy produces 
improvement on bone microarchitecture before its known effect on imparired bone mineral density.

\section{Conclusion}

We found that HRT corrects impaired bone microarcitecture which develops before impairement of BMD in a rat model with surgically induced early menopause. Therefore, estrogen alone or in combination with progestogen can be a beneficial approach to preventing early postmenopausal bone loss.

\section{Conflict of interest}

No conflict of interest was declared by the authors.

\section{References}

1. Brandi ML. Microarchitecture, the key to bone quality. Rheumatology (Oxford) 2009; 48: 3-8. [CrossRef]

2. NIH Consensus Development Panel on Osteoporosis Prevention Diagnosis, and Therapy. Osteoporosis prevention, diagnosis, and therapy. JAMA 2001; 285: 785-95. [CrossRef]

3. Kalpakcioglu BB, Morshed S, Engelke K, Genant HK. Advanced imaging of bone macrostructure and microstructure in bone fragility and fracture repair. J Bone Joint Surg Am 2008; 90: 68-78. [CrossRef]

4. Cummings SR, Bates D, Black DM. Clinical use of bone densitometry: scientific review. JAMA 2002; 288: 1889-97. [CrossRef]

5. Zebaze RM, Ghasem-Zadeh A, Bohte A, Iuliano-Burns S, Mirams $\mathrm{M}$, Price RI, et al. Intracorticalremodelling and porosity in the distal radius and post-mortem femurs of women: a cross-sectional study. Lancet 2010; 375: 1729-36. [CrossRef]

6. Siris ES, Miller PD, Barrett-Connor E, Faulkner KG, Wehren LE, Abbott TA, et al. Identification and fracture outcomes of undiagnosed low bone mineral density in postmenopausal women: results from the National Osteoporosis Risk Assessment. JAMA 2001; 286: 2815-22. [CrossRef]

7. Kleerekoper M. Osteoporosis prevention and therapy: preserving and building strength through bone quality. Osteoporos Int 2006; 17: 1707-15. [CrossRef]

8. Genant HK, Engelke K, Prevrhal S. Advanced CT bone imaging in osteoporosis. Rheumatology (Oxford) 2008; 47: 9-16. [CrossRef]

9. Aitken JM, Lindsay R, Hart DM. Long-term oestrogens for the prevention of post-menopausal osteoporosis. Postgrad Med J 1976; 52: $18-26$.

10. Christiansen C, Christensen MS, Transbol I. Bone mass in postmenopausal women after withdrawal of oestrogen/gestagen replacement therapy. Lancet 1981; 1: 459-61. [CrossRef]

11. Wells G, Tugwell P, Shea B, Guyatt G, Peterson J, Zytaruk N, et al. Meta-analyses of therapies for postmenopausal osteoporosis. V. Meta-analysis of the efficacy of hormone replacement therapy in treating and preventing osteoporosis in postmenopausal women. Endocr Rev 2002: 23: 529-39. [CrossRef]

12. Yates J, Barrett-Connor E, Barlas S, Chen YT, Miller PD, Siris ES. Rapid loss of hip fracture protection after estrogen cessation: evidence from the National Osteoporosis Risk Assessment. ObstetGynecol 2004; 103: 440-6. [CrossRef]

13. Cauley JA, Robbins J, Chen Z, Cummings SR, Jackson RD, LaCroix $\mathrm{AZ}$, et al. Effects of estrogen plus progestin on risk of fracture and bone mineral density: the Women's Health Initiative randomized trial. JAMA 2003; 290: 1729-38. [CrossRef]

14. Tiihonen M, Saarela M, Saarinen S, Ahonen R, Heikkinen AM. Menopausal hormone therapy-benefits, adverse reactions, concerns and information sources in 2009. Maturitas 2011; 70: 69-73. [CrossRef]
15. Bancroft JD, Stevens A. Theory and practice of histological techniques. 3rd ed. Churchill Livingstone, Edinburgh 1990.

16. Cui L, Wu T, Liu YY, Deng YF, Ai CM, Chen HQ. Tanshinone prevents cancellous bone loss induced by ovariectomy in rats. Acta Pharmacol Sin 2004; 25: 678-84.

17. Hanyu T, Chotanaphuti $\mathrm{T}$, Arai $\mathrm{K}$, Tanaka $\mathrm{T}$, Takahashi HE. Histomorphometric assessment of bone changes in rats with type II collagen-induced arthritis. Bone 1999;24:485-90. [CrossRef]

18. Parfitt AM, Drezner MK, Glorieux FH, Kanis JA, Malluche H, Meunier PJ, et al. Bone histomorphometry: standardization of nomenclature, symbols, and units. Report of the ASBMR Histomorphometry Nomenclature Committee. J Bone Miner Res 1987; 2: 595-609. [CrossRef]

19. Khastgir G, Studd J, Holland N, Alaghband-Zadeh J, Fox S, Chow J. Anabolic effect of estrogen replacement on bone in postmenopausal women with osteoporosis: histometricevidance in a longitudinal study. J Clin EndocrinolMetab 2001; 86: 289-95. [CrossRef]

20. Center JR, Nguyen TV, Schneider D, Sambrook PN, Eisman JA. Mortality after all major types of osteoporotic fracture in men and women: an observational study. Lancet 1999; 353: 878-82. [CrossRef]

21. Dempster DW. Anatomy and functions of the adult skeleton. In: Favus MJ editor. Primer on the metabolic bone diseases and disorders of mineral metabolism, 6th ed. Washington, DC: American Society for Bone and Mineral Research; 2006, p. 7-11.

22. Bagi CM, DeLeon E, Ammann P. Histo-anatomy of the proximal femur in rats: impact of ovariectomy on bone mass, structure, and stiffness. Anat Rec 1996; 245: 633-44. [CrossRef]

23. Ladinsky GA, Vasilic B, Popescu AM, Wald M, Zemel BS, Snyder PJ, et al. Trabecular structure quantified with the MRI-based virtual bone biopsy in postmenopausal women contributes to vertebral deformity burden independent of areal vertebral BMD. J Bone Miner Res 2008; 23: 64-74. [CrossRef]

24. Siris ES, Brenneman SK, Barrett-Connor E, Miller PD, Sajjan S, Berger ML, et al. The effect of age and bone mineral density on the absolute, excess, and relative risk of fracture in postmenopausal women aged 50-99: results from the National Osteoporosis Risk Assessment (NORA). OsteoporosInt 2006; 17: 565-74. [CrossRef]

25. Santen RJ, Allred DC, Ardoin SP, Archer DF, Boyd N, Braunstein GD, et al. Endocrine Society. Postmenopausal hormone therapy: an Endocrine Society scientific statement. J Clin Endocrinol Metab 2010; 95: 1-66. [CrossRef]

26. Vedi S, Compston JE. The effects of long-term hormone replacement therapy on bone remodeling in postmenopausal women. Bone 1996; 19: 535-9. [CrossRef]

27. Holland EF, Chow JW, Studd JW, Leather AT, Chambers TJ. Histomorphometric changes in the skeleton of postmenopausal women with low bone mineral density treated with percutaneous estradiol implants. Obstet Gynecol 1994; 83: 387-91.

28. Kousteni S, Bellido T, Plotkin LI, O'Brien CA, Bodenner DL, Han $\mathrm{L}$, et al. Nongenotropic, sex-nonspecific signaling through the estrogen or androgen receptors: Dissociation from transcriptional activity. Cell 2001; 104: 719-30. [CrossRef]

29. Lindsay R. The lack of effect of progestogen on bone. J Reprod Med 1999; 44: 215-20.

30. Imai Y, Kondoh S, Kouzmenko A, Kato S. Minireview: osteoprotective action of estrogens is mediated by osteoclastic estrogen receptor-alpha. Mol Endocrinol 2010; 24: 877-85. [CrossRef]

31. Komm BS, Vlasseros F, Samadfam R, Chouinard L, Smith SY. Skeletal effects of bazedoxifene paired with conjugated estrogens in ovariectomized rats. Bone 2011; 49: 376-86. [CrossRef]

32. Oner G, Ozcelik B, Ozgun MT, Serin IS, Ozturk F, Basbug M. The effects of metformin and letrozole on endometriosis and comparison of the two treatment agents in a rat model.. J Turkish-German Gynecol Assoc 2007; 8: 22-8. 